\title{
Rola Wydawnictwa Łódzkiego Towarzystwa Naukowego w utrwalaniu i upowszechnianiu osiągnięć badawczych oraz doświadczeń edukacyjnych przedstawicieli łódzkiego środowiska naukowego
}

\section{Kształtowanie się organizacji scalającej łódzkie środowisko naukowe}

W XIX w. Łódź stała się miastem, w którym wzmożony rozwój gospodarki wiązał się z gwałtownym rozwojem ludnościowym. Niestety, nie towarzyszył temu równie intensywny rozwój oświaty i kultury. Mimo inicjatyw i potrzeb miejscowego społeczeństwa, władze zaborcze nie dopuściły do powstania wyższej uczelni. Ta sytuacja spowodowała, że jedynie stowarzyszenia reprezentujące interesy zawodowe swych członków mogły podejmować działalność naukową.

Najwcześniej powołano do życia Łódzkie Towarzystwo Lekarskie (31.08.1886 r.). Powstałe w jego ramach sekcje - pediatryczna i psychiatryczna - prowadziły działalność naukową ${ }^{1}$. W tym samym czasie uaktywnili się łódzcy nauczyciele, tworząc stowarzyszenia, które, obok obrony ich interesów zawodowych, zajęły się popularyzacją wiedzy naukowej. Szczególnie ważną rolę odegrało w tym zakresie Towarzystwo Wzajemnej Pomocy Czynnych i Byłych Nauczycieli i Nauczycielek Wyznania Chrześcijańskiego ${ }^{2}$. W latach 1905-1907 pojawiły się w Łodzi stowarzyszenia

* Dr, Uniwersytet Łódzki, Wydział Nauk o Wychowaniu, Katedra Historii Wychowania i Pedeutologii, 91-408 Łódź, ul. Pomorska 46/48.

${ }^{1}$ W. Markert, Działalność Łódzkiego Towarzystwa Lekarskiego na przełomie XIX i XX wieku, „Sprawozdania z Czynności i Posiedzeń Naukowych” 1987, nr 3, s. 1-6. Członkami Towarzystwa byli lekarze, farmaceuci, weterynarze. Badania naukowe prowadzono głównie w łódzkich szpitalach.

${ }^{2}$ B. Szwalm, O najstarszej organizacji nauczycielskiej pn. Towarzystwo Wzajemnej Pomocy Obecnych i Byłych Nauczycieli i Nauczycielek Chrześcijan m. Łodzi (1898-1918), [w:] 50-lecie 
naukowo-oświatowe zrzeszające przedstawicieli różnych dziedzin i zawodów. Towarzystwo Krzewienia Oświaty, Łódzki Oddział Macierzy Szkolnej, Łódzkie Towarzystwo „Wiedza”, organizując odczyty dla dorosłych i pogadanki dla młodzieży, popularyzowały zdobycze nauki ${ }^{3}$.

W okresie międzywojennym w Łodzi zwiększyła się liczba stowarzyszeń ogólnych i specjalistycznych. Rozszerzył się ich zakres merytoryczny o nowe dziedziny. Powstały organizacje skupiające historyków, geografów, przedstawicieli nauk przyrodniczych, prawników, ekonomistów, miłośników języka polskiego, przyjaciół sztuk pięknych, techników. Część specjalistycznych stowarzyszeń stanowiła filie organizacji ogólnopolskich. Obok nich utworzono towarzystwa szkolno-oświatowe skupiające przedstawicieli mniejszości narodowych i religijnych ${ }^{4}$.

Realizacja celów naukowych stawała się łatwiejsza, gdy do stowarzyszeń zaczęli zgłaszać swój akces wykładowcy miejscowych szkół półwyższych i wyższych. Status uczelni akademickich uzyskały w Łodzi dwie placówki - Wyższe Seminarium Duchowne i Oddział Łódzki Wolnej Wszechnicy Polskiej5.

W latach 30. pojawiły się $w$ Łodzi inicjatywy stworzenia jednej organizacji integrującej łódzkie środowisko naukowe. Zwolennicy wprowadzenia tej zasadniczej zmiany dowodzili, że podział na stowarzyszenia specjalistyczne utrudniał nieraz działalność programową i pełne wykorzystanie środków przeznaczonych na działalność statutową. W 1934 r. z pomysłem stworzenia regionalnego towarzystwa naukowego wystąpił prezes Oddziału Łódzkiego Polskiego Towarzystwa Historycznego, Zygmunt Lorentz. Rozmowy w tej sprawie prowadził z przedstawicielami Towarzystw: Lekarskiego, Prawniczego i Techników. W prace przygotowawcze zaangażował się rektor Oddziału Łódzkiego WWP, profesor Teodor Vieweger. W wyniku tych wspólnych działań wypracowano koncepcję nowej organizacji - Towarzystwa Przyjaciół Nauk w Łodzi. W dniu 19 listopada 1936 r. zarejestrowano statut organizacji. Wkrótce, 15 stycznia 1937 r. ukonstytuowały się władze Towarzystwa6.

W „Statucie” w następujący sposób określono cele Towarzystwa: „Celem Towarzystwa Przyjaciół Nauk w Łodzi jest rozwój nauki we wszystkich gałęziach wiedzy, a w szczególności inicjowanie i popieranie naukowej pracy badawczej

Związku Nauczycielstwa Polskiego w Łodzi 1918-1968, „Biuletyn Historyczny”, red. M. Bandurka, Łódź 1968, s. 7-9.

${ }^{3}$ M. Bandurka, Walka o oświatę i szkolnictwo polskie w latach rewolucji 1905-1907 w Łodzi i okręgu. Studia i materiały, red. B. Wachowska, Łódź 1975, s. 109-110, 123-125; J. Stemler, Polska Macierz Szkolna, [w:] Nasza walka o szkołę polską 1901-1917. Opracowania, wspomnienia, dokumenty, red. B. Nawroczyński, t. 2, Warszawa 1934, s. 177.

${ }^{4}$ J. Kuciński, Łódzkie Towarzystwo Naukowe w latach 1936-1996, cz. 1, Studia, Łódź 1996, s. $25-33$.

${ }^{5}$ K. Baranowski, Początki Łodzi akademickiej, Łódź 1993, s. 67-96; T. Jałmużna, Z dziejów akademickiej Łodzi. Wyższa Szkoła Pedagogiczna 1946-1956, Łódź 1996, s. 8-20.

6 J. Dylik, Powstanie Łódzkiego Towarzystwa Naukowego na tle kulturalnego rozwoju środowiska, „Sprawozdania z Czynności i Posiedzeń” 1947, nr 1, s. 5. Prezesem Zarządu Tymczasowego, a potem Zarządu powstałego 4.12.1938 r. był prof. T. Vieweger, zaś sekretarzem generalnym Z. Lorentz. 
w sprawie potrzeb nauki na terenie Łodzi i województwa łódzkiego"”. Przewidywano druk prac naukowych w postaci wydawnictw periodycznych lub oddzielnych publikacji. Opracowania naukowe planowano wiązać z badaniami regionalnymi. TPNŁ było zbliżone charakterem do Towarzystwa Przyjaciół Nauk w Wilnie. Dopuszczano zatem wydawanie prac popularnych, tłumaczeń dysertacji naukowych i kompilacji ${ }^{8}$.

Członkowie Towarzystwa podejmowali działalność w ramach sekcji i komisji. Zgodnie ze statutem wyodrębniono dwie Sekcje: I. Nauk Matematyczno-Przyrodniczych i II. Nauk Humanistycznych. Okazało się, że aktywność tych sekcji ukierunkowała się głównie na popularyzację wiedzy naukowej. Do wybuchu II wojny światowej nie udało się przeprowadzić zamierzonych badań regionalnych i zaprezentować ich w publikacjach.

Na okres II wojny światowej Towarzystwo zawiesiło działalność. Wznowiło ją w marcu 1945 r. Do reaktywacji organizacji przyczynił się w dużej mierze prof. T. Vieweger wspierany przez prof. Jana Dylika i pracowników Oddziału Łódzkiego WWP. Starali się oni kontynuować działania zainicjowane przed 1939 r. Ten kierunek był widoczny również po tragicznej śmierci prezesa Towarzystwa9 ${ }^{9}$.

Pojawiły się jednak głosy domagające się przekształcenia stowarzyszenia w towarzystwo naukowe. Do Łodzi w 1945 r. przybyli pracownicy naukowi z ośrodków o odmiennych tradycjach akademickich (Lwów, Wilno, Warszawa).Występowały wśród nich różnice stanowisk dotyczących zarówno modelu szkół wyższych, jak też wizji towarzystwa naukowego. Toczono spory, które zakończyły się utworzeniem Łódzkiego Towarzystwa Naukowego. Okazało się, że projekt nowego statutu został opracowany z udziałem byłych członków Towarzystwa Przyjaciół Nauk, a odpowiedzialne funkcje (sekretarz generalny, przewodniczący wydziału) niejednokrotnie pełniły osoby również znane ze swej aktywności w „starym” Towarzystwie. W ten sposób Łódzkie Towarzystwo Naukowe stało się kontynuatorem Towarzystwa Przyjaciół Nauk ${ }^{10}$.

W dniu 3.03.1946 r. na Nadzwyczajnym Zebraniu Towarzystwa Przyjaciół Nauk w Łodzi przyjęto statut nowego Towarzystwa i przekazano mu majątek. Dopiero jednak 24.01.1948 r. prezydent Łodzi zarejestrował statut i tym samym zakończyło się od strony prawnej przekształcanie organizacji11.

${ }^{7}$ Statut Towarzystwa Przyjaciół Nauk w Łodzi, Łódź 1937, s. 3-4.

8 J. Kuciński, Łódzkie Towarzystwo Naukowe..., s. 44-45.

9 Profesor Teodor Mieczysław Vieweger. Sylwetki łódzkich uczonych, red. J. Kuciński, z. 63, Łódź 2001, s. 19-20; J. Kuciński, Łódzkie Towarzystwo Naukowe..., s. 47. T. Vieweger pełnił funkcję prezesa TPNŁ do 22.05.1945 r. Po nim w okresie przekształcania stowarzyszenia obowiązki prezesa wykonywali: historyk Ludwik Kolankowski (23.06.1945 - 12.05.1946) i fizyk Marian Grotowski (12.05.1946-30.11.1946).

${ }^{10}$ W. Śmiech, Łódzkie Towarzystwo Naukowe, [w:] Słownik polskich towarzystw naukowych, red. D. Smoleński, t. 1, Wrocław 1978, s. 60.

11 J. Kuciński, Łódzkie Towarzystwo Naukowe..., s. 59. Prezydent m. Łodzi zarejestrował Statut ŁTN na podstawie „Prawa o stowarzyszeniach” z 27.10.1932 r. 


\section{Cele i główne kierunki działalności Łódzkiego Towarzystwa Naukowego}

Organizacja, cele i kierunki działania ŁTN zostały określone w statucie zatwierdzonym w 1946 r. W czasie funkcjonowania Towarzystwa był on wielokrotnie zmieniany. Reformy „Statutu” najczęściej dotyczyły zmian strukturalnych. Ich charakter zależał od polityki państwa dotyczącej rozwoju polskiej nauki, jak też uwarunkowań lokalnych.

„Statut” ŁTN z 3.03.1946 r. określił terytorialny i merytoryczny zakres działania organizacji. Siedzibą jej była Łódź, lecz terenem oddziaływania stawał się cały kraj. Stwierdzano, że głównym celem $Ł T N$ będzie rozwój i popieranie badań naukowych jednak $w$ ich ramach nie eksponowano prac badawczych na rzecz regionu. W „Statucie” tym określono, że stowarzyszenie składa się z czterech Wydziałów:

I Językoznawstwa, Nauki o Literaturze i Filozofii,

II Nauk Historycznych i Społecznych,

III Nauk Matematyczno-Przyrodniczych,

IV Nauk Medycznych.

Okazało się, że Wydział IV w tym czasie jeszcze nie istniał, a zapis w „Statucie" $Ł T N$ był jego zapowiedzią. Wydział Nauk Medycznych utworzono w dniu 10.11.1949 r. ${ }^{12}$ Gdy okazało się, że Wydział III nie w pełni uwzględnia zainteresowania i potrzeby pracowników Politechniki Łódzkiej, w dniu 13.12.1956 r. uruchomiono $w \in$ TN Wydział $\vee$ Nauk Technicznych ${ }^{13}$.

Członkowie wymienionych Wydziałów koncentrowali swą aktywność wokół trzech nurtów: badań naukowych, upowszechniania wiedzy naukowej i działalności wydawniczej.

Zmiany „Statutu” zapoczątkowane w latach 50. XX w. związane były z utworzeniem Polskiej Akademii Nauk (30.10.1951 r.). Instytucji tej został podporządkowany społeczny ruch naukowy. Regionalne towarzystwa naukowe utraciły suwerenność, a część z nich uległa likwidacji. Byt ŁTN został poważnie zagrożony. Głównie starania członków Zarządu z prezesem prof. T. Kotarbińskim na czele uratowały Towarzystwo przed likwidacją ${ }^{14}$.

Przede wszystkim presja PAN spowodowała uchwalenie nowej wersji statutu ŁTN w dniu 18.04.1964 r..$^{15}$ Znamiennym dla tamtych czasów stał się zapis dotyczący celów realizowanych przez Towarzystwo. Podano, że „celem jest popieranie rozwoju nauki we wszystkich dziedzinach, ze szczególnym uwzględ-

12 S. Liszewski, Łódzkie Towarzystwo Naukowe 1936-1996, „Problemy Społecznego Ruchu Naukowego" 1998, t. 4, cz. 1, s. 151.

13 J. Kuciński, Łódzkie Towarzystwo Naukowe..., s. 76.

14 Tamże, s. 68. Prof. T. Kotarbiński pełnił funkcję prezesa ŁTN w latach 1946-1966.

${ }^{15}$ Statut Łódzkiego Towarzystwa Naukowego z 18.04.1964 r. został zarejestrowany przez Urząd Spraw Wewnętrznych Prezydium Rady Narodowej m. Łodzi w dniu 12.07.1965 r. 
nieniem dziedzin ważnych dla miasta Łodzi i województwa łódzkiego oraz rozbudzanie życia naukowego na tym terenie i wiązanie go z budownictwem socjalizmu w Polsce"16. W dokumencie znalazły się także zapisy dotyczące kontaktów ŁTN z centralnymi i lokalnymi władzami administracyjnymi i samorządowymi. Mowa była o opracowywaniu na zlecenie tych organów opinii i innych materiałów naukowych.

Istotne zmiany w statucie ŁTN nastąpiły po stworzeniu w Polsce nowych podstaw prawnych dla działalności towarzystw naukowych. Kwestie te regulowała „Ustawa z 7 kwietnia 1989 r. Prawo o stowarzyszeniach"17. Uwzględniając ten dokument, Ogólne Zgromadzenie Członków uchwaliło w dniu 29.03.1990 r. nową wersję statutu ŁTN ${ }^{18}$. Przede wszystkim w tekście nie było zapisów dotyczących wpływu ideologii (socjalistycznej) na rozwój badań naukowych.

W ciągu ostatnich dwudziestu lat kilkakrotnie wprowadzano zmiany do statutu ŁTN. Wpływ na to miały czynniki, które po 1989 r. kształtowały charakter społecznego ruchu naukowego w różnych aspektach jego działalności. PAN przestała dotować towarzystwa naukowe i wpływać na kierunek ich działalności wydawniczej. Od 1991 r. finansowaniem polskiej nauki zajął się Komitet Badań Naukowych (KBN). ŁTN otrzymywała od KBN środki do 2005 r. Nie w pełni wystarczały one na realizację planów. Ważne stało się wówczas uzyskanie jak największych subwencji samorządu terytorialnego i materialnego wsparcia fundacji.

Po 1989 r. nastąpiła w ŁTN jedna widoczna zmiana strukturalna. Uwzględniając potrzebę znalezienia formuły wstępowania do Towarzystwa pracowników Akademii Muzycznej i Państwowej Wyższej Szkoły Sztuk Plastycznych, podjęto decyzję o powołaniu VI Wydziału. W dniu 1.04.1996 r. Zwyczajne Zgromadzenie Ogólne ŁTN uchwaliło utworzenie Wydziału VI Sztuk i Nauk o Sztuce ${ }^{19}$.

W ostatnich latach w funkcjonowaniu $Ł T N$ zaobserwować można pojawienie się nowych form działalności. „Statut” z 29.03.2010 r. stanowi, że do osiągnięcia celów trzeba skupić się na realizacji pięciu zadań. Należą do nich:

- integracja środowiska akademickiego Łodzi;

- działalność wydawnicza;

- działalność naukowo-badawcza;

- działalność edukacyjna (wykłady metodologiczne na studiach doktoranckich, prace nad programem i podręcznikami do „nauczania regionalnego”);

- promocja osiągnięć naukowych (współorganizator Festiwalu Nauki, Techniki i Sztuki).

${ }^{16}$ Statut Łódzkiego Towarzystwa Naukowego z 18.04.1964 r., Łódź 1964, s. 1-2.

17 Ustawa z 7 kwietnia 1989 r. Prawo o stowarzyszeniach, Dziennik Ustaw Polskiej Rzeczypospolitej Ludowej, 1989, nr 20, poz. 104.

18 J. Ławrynowicz, Sprawozdanie sekretarza generalnego $Ł T N$ za lata 1982-1991, „Sprawozdania z Czynności i Posiedzeń ŁTN 1982-1991”, Łódź 1993, s. 7.

19 J. Kuciński, Łódzkie Towarzystwo Naukowe..., s. 77. 


\section{Działalność wydawnicza jako podstawowa forma aktywności Łódzkiego Towarzystwa Naukowego}

We wszystkich statutach ŁTN (poczynając od pierwszego z 1946 r.) znalazły się zapisy świadczące o tym, że bardzo dużą wagę przywiązywano do działalności wydawniczej. Wydawnictwo stało się pierwszym elementem integrującym środowisko naukowe Łodzi, szansą na prezentowanie i upublicznianie wyników badań.

Rozwój aktywności wydawniczej ŁTN zależał od szeregu czynników. Możemy tutaj wskazać uwarunkowania lokalne oraz wpływy zewnętrzne związane z określoną polityką władz centralnych. Państwo decydowało o finansowaniu produkcji wydawniczej i jej cenzurowaniu. Narzucało ideologię, która decydować miała o metodologii badań naukowych. Rzecznikiem interesów państwa przez długi czas była PAN. Przedstawiciele PAN pełnili funkcję nadzorczą: recenzowali publikacje ŁTN, określali limity wydawnicze (liczby tytułów i wielkość nakładów), zatwierdzali środki finansowania dla działalności wydawniczej. Jeśli zaś chodzi o wpływ czynników miejscowych, to należy brać pod uwagę wielkość potencjału naukowego Łodzi i współpracę ŁTN z wyższymi uczelniami w mieście. Dopiero w wyniku zmian ustrojowych po 1989 r. wydawnictwo ŁTN mogło prowadzić samodzielną politykę.

Uwzględniając powyższe uwarunkowania, można wyodrębnić trzy zasadnicze etapy w aktywności wydawnictwa ${ }^{20}$. Zamykają się one w następujących odcinkach czasowych: I. 1946-1949; II. 1950-1989; III. 1990- (do chwili obecnej).

\subsection{Okres niezależności od wpływów politycznych -1946-1949}

W latach 1945-1946 profesorowie z Uniwersytetu Łódzkiego zasugerowali władzom uczelni utworzenie własnego wydawnictwa naukowego. Ówczesny rektor UŁ, a zarazem prezes ŁTN, biorąc pod uwagę międzywojenny model organizacji życia naukowego, optował za tym, aby działalnością wydawniczą zajęło się stowarzyszenie naukowe. ŁTN stało się niebawem najważniejszym wydawcą dla łódzkich akademików. Przede wszystkim w pierwszej fazie kształtowania się UŁ stało się nieoficjalną oficyną wydawniczą tej uczelni. Ogłaszano drukiem prace, które ze względu na podjęty temat i zastosowane metody badań nie zyskały aprobaty innych wydawców. Decydowano się na edycje niskonakładowe, jeśli tylko praca zyskiwała bardzo dobre recenzje.

20 Dokładne dane dotyczące publikacji wydawnictwa ŁTN zawierają następujące prace: Katalog wydawnictw ŁTN 1946-1955, red. M. Hessenowa, Łódź 1956; Katalog wydawnictw ŁTN 19451969, red. W. Śmiech, Łódź 1971; Katalog wydawnictw ŁTN 1970-1973, red. W. Śmiech, oprac. H. Klimkiewicz, Łódź 1974; Bibliografia wydawnictw Towarzystwa Przyjaciół Nauk w Łodzi w latach 1936-1946 i Łódzkiego Towarzystwa Naukowego w latach 1946-2005, oprac. A. Walczak-Niewiadomska, Łódź 2006. 
W 1948 r. nastąpił podział zadań w działalności wydawniczej. ŁTN podjęło się publikowania prac z zakresu nauk humanistycznych, matematyczno-przyrodniczych oraz prawno-ekonomicznych. UŁ stał się odpowiedzialny za druk podręczników uniwersyteckich, wykładów powszechnych wygłaszanych przez kadrę profesorów uczelni i prac reprezentujących wyniki badań nauk medycznych ${ }^{21}$.

W 1947 r. ukazały się pierwsze publikacje ŁTN. Szczegółowych informacji dotyczących funkcjonowania Towarzystwa dostarczały „Sprawozdania z Czynności i Posiedzeń” ŁTN. W ciągu pierwszych lat wydawania „Sprawozdań” kilkakrotnie zmieniano koncepcję publikacji. Ustalono, że rocznik powinien składać się z dwóch części: sprawozdawczej i merytorycznej. W części merytorycznej umieszczano referaty wygłaszane na posiedzeniach naukowych wydziałów i ich streszczenia. „Sprawozdania” wydawano do 1950 r. w nakładzie 1000 egzemplarzy. Zapewnić to miało popularyzację osiągnięć Towarzystwa w środowisku akademickim.

W roku 1947 powstała seria wydawnicza „Prace Wydziałów”. Na początku ukazały się „Prace Wydziału I - Językoznawstwa, Nauki o Literaturze i Filozofii” i „Prace Wydziału II - Nauk Matematyczno-Przyrodniczych”. Znamienne jest, że te drugie zawierały plon pracy uczonych, którzy mieli bardzo trudne warunki do prowadzenia badań w organizujących się uczelniach wyższych. W 1948 r. wydany został pierwszy tom „Prac Wydziału III - Historii i Nauk Społecznych”. W ramach tej serii pojawiło się bardzo dużo prac indywidualnych. Miały one na początku charakter monografii i prac przeglądowych zapoznających czytelników z wynikami prac badawczych w różnych dyscyplinach. Z czasem dołączyły do nich eseje, szkice literackie i podręczniki akademickie.

Uruchomienie serii „Prac Wydziałów” pobudziło aktywność twórczą przedstawicieli łódzkiego środowiska naukowego. Duża częstotliwość ukazywania się kolejnych tomów przyczyniała się do zintensyfikowania wysiłku badawczego, którego plonem stawały się niejednokrotnie wybitne dzieła. Do ich autorów należeli przedstawiciele: Wydziału I - Tadeusz Kotarbiński, Zdzisław Stieber, Stefania Skwarczyńska; Wydziału II - Bohdan Baranowski, Konrad Jażdżewski, Stanisław Zajączkowski; Wydziału III - Jan Dylik22.

W 1948 r. zaczęto w ramach serii wydawniczych publikować dwa czasopisma przedstawiające dorobek naukowy członków ŁTN, reprezentujących środowisko archeologów i geografów. Prof. K. Jażdżewski zainicjował serię wydawniczą „Acta Archaeologica Lodziensia”. Publikacje zamieszczane w tym czasopiśmie cechowała różnorodność tematyczna, szeroki zakres czasowy (od epoki kamienia do współczesności) i integracyjny charakter (prace na styku archeologii z innymi dziedzinami nauki). Z kolei prof. J. Dylik założył nową serię wydawniczą „Acta Geographica Lodziensia". Zaczęto umieszczać tam prace oparte na badaniach terenowych prowadzonych głównie w Polsce Środkowej. W późniejszym okresie tematyka opracowań przekroczyła ramy regionalne. W 1949 r. Wydział III zaczął

21 T. Kotarbiński, Łódzkie Towarzystwo Naukowe, „Przegląd Nauk Historycznych i Społecznych", t. 2, 1952, s. 331-334.

22 Bibliografia wydawnictw Towarzystwa Przyjaciół Nauk..., s. 11-12. 
zamieszczać publikacje w ramach serii „Acta Anthropologica Lodziensia” pod redakcją prof. Ireneusza Michalskiego.

W pierwszym okresie działalności wydawnictwo $\measuredangle T N$ było finansowane przez Ministerstwo Oświaty, a potem przez Ministerstwo Szkolnictwa Wyższego i Nauki. Te organy państwowe oraz Wojewódzki i Główny Urząd Kontroli Prasy, Publikacji i Widowisk wyłoniły Komisję Kwalifikacyjną, która stała się cenzorem wydawnictw Towarzystwa. Do przełomu lat 1948 i 1949 ŁTN cieszyło się swobodą wydawniczą. Represyjna cenzura pojawiła się jednak niebawem.

\subsection{Podporządkowanie wydawnictwa $Ł T N$ zarządzeniom PAN (1950-1989)}

Począwszy od 1949 r. władze polityczne w Polsce w ramach prowadzonej polityki naukowej podjęły działania w celu podporządkowania sobie towarzystw naukowych, pojawiły się postulaty powiązania nauki z gospodarką i administracją poprzez wprowadzenie w życie planowania badań naukowych. Przygotowaniom do I Kongresu Nauki Polskiej towarzyszyły zjazdy naukowców, na których wskazywano kierunki zmian w rozwoju badań w ramach różnych dyscyplin. Zapowiadano przełom ideologiczny w naukach humanistycznych i społecznych ${ }^{23}$.

Następstwem uchwał I Kongresu Nauki Polskiej stało się powołanie do życia Polskiej Akademii Nauk24. Od 1951 r. PAN stała się najważniejszą instytucją dotującą działalność wydawniczą ŁTN. W pierwszej połowie lat 50. wprowadzono wielopiętrowy system cenzury. Najniższy szczebel stanowiły komisje redakcyjne i komisje wydziałowe $Ł T N$ oceniające wartość naukową i ideologiczną prac zgłoszonych do druku. Najwyższym jednak organem decyzyjnym była Komisja Kwalifikująca działająca $w$ ramach PAN.

Już w 1950 r. wydawnictwo ŁTN odczuło skutki cenzury Ministerstwa Szkolnictwa Wyższego i Nauki. Dotyczyła ona prac monograficznych z dziedziny botaniki i zoologii oraz nowego czasopisma „Bulletin de la Société des Sciences et des Lettres de Łódź". Pierwszy tom tego czasopisma obejmował opracowania w języku francuskim i angielskim zaprezentowane w formie referatów w latach 1945-194725.

W następnym roku wydawnictwo ŁTN zapoczątkowało druk „Prac Wydziału IV - Nauk Medycznych" pod redakcją Wacława Markertera ${ }^{26}$. Sukcesem zakończyły się też starania historyków i socjologów, ponieważ od 1951 r. zaczął się ukazywać „Przegląd Nauk Historycznych i Społecznych”. Redaktorami tego czasopisma kolejno byli: Józef Chałasiński, Natalia Gąsiorowska i Marian Henryk Serejski ${ }^{27}$.

${ }^{23}$ P. Hübner, I. Kongres Nauki Polskiej jako forma realizacji założeń polityki naukowej państwa ludowego, Wrocław 1983, s. 79.

24 Ustawa z dnia 30 października 1951 r. o Polskiej Akademii Nauk, Dziennik Ustaw Rzeczypospolitej Polskiej, 1951, nr 57, poz. 391.

${ }^{25}$ Bibliografia wydawnictw Towarzystwa Przyjaciół Nauk..., s. 13, 151-164.

26 Tamże, s. 14.

27 Tamże, s. 217-220. W latach 1951-1958 wydano 7 tomów. 
W 1954 r. pojawiły się nowe wydawnictwa ciągłe. Należały do nich: „Biuletyn Peryglacyjny", w którym zamieszczano najpierw w języku polskim, a potem w językach francuskim i angielskim prace dotyczące geomorfologii ${ }^{28}$ oraz „Rozprawy Komisji Językowej” prezentujące wiedzę lingwistyczną o języku polskim i językach słowiańskich ${ }^{29}$. W 1955 r. ukazał się pierwszy tom czasopisma „Acta Chimica"30.

Od 1951 r. do PAN należało zatwierdzenie planu wydawniczego ŁTN i jego finansowanie, wskazanie oficyny wydawniczej, do której ŁTN miała złożyć materiały, określanie wysokości nakładu i sposobu jego sprzedaży.

W 1956 r. przedstawiciele polskiej nauki spodziewali się, że „odwilż polityczna" doprowadzi do demokratycznych zmian w społecznym ruchu naukowym. Nowym prezesem PAN został T. Kotarbiński, który mówił o potrzebie wprowadzenia partnerskiego stosunku Akademii do towarzystw naukowych. Prof. Józef Chałasiński jesienią 1956 r. zapowiedział, że ŁTN uzyska większą samodzielność i będzie mogło prowadzić politykę wydawniczą zgodną ze swoimi potrzebami.

Najbliższe lata wykazały jednak, że PAN nadal roztaczał „opiekę” nad ŁTN. Wprawdzie dotacje w latach 1956-1962 zwiększyły się, ale już w 1963 r. nastąpiło ograniczenie planu wydawniczego. W tych trudnych warunkach następowało jednak wzbogacanie oferty wydawniczej Towarzystwa. Przede wszystkim do publikacji ŁTN dołączyły dwa czasopisma mające duży zasięg oddziaływania i coraz mocniejszą pozycję ogólnopolską.

W 1957 r. ŁTN przejął od Polskiego Instytutu Socjologicznego ukazujący się od 1930 r. „Przegląd Socjologiczny”. Jego pierwszym redaktorem został w Łodzi prof. J. Chałasiński. Czasopismo zawierające publikacje socjologów ukazywało się w nakładzie 1200 egzemplarzy.

W 1958 r. wydawnictwo ŁTN przejęło czasopismo „Prace Polonistyczne” założone w 1937 r. z inicjatywy przedstawicieli Oddziału Łódzkiego WWP. Redaktorem został prof. Zdzisław Skwarczyński. W tym samym czasie pojawił się pierwszy tom wydawnictwa ciągłego „Zagadnienia Rodzajów Literackich” redagowany przez prof. Stefanię Skwarczyńską. Oba czasopisma najpierw pełniły rolę forum łódzkiego środowiska polonistycznego, a z czasem zyskały mocną pozycję w kraju.

W 1961 r. powołano nową serię wydawniczą „Szlakami nauki”. W jej ramach zaczęto wydawać prace o charakterze popularno-naukowym. Miały one trafiać do szerszego kręgu czytelników i zaznajamiać ich z osiągnięciami łódzkiego środowiska naukowego ${ }^{31}$. Od 1971 r. kolejne tomy tej serii miały wyłącznie charakter badawczy.

${ }^{28}$ Tamże, s. 135-151. Pierwszym redaktorem był prof. J. Dylik. W latach 1954-2000 wydano 39 tomów.

29 Tamże, s. 242-260. Pierwszym redaktorem był prof. Z. Stieber. W latach 1954-2012 wydano 57 tomów.

${ }^{30}$ Tamże, s. 121-131. Pierwszym redaktorem była prof. A. Chrząszczewska. W latach 19551973 wydano 18 tomów.

${ }^{31} \mathrm{~W}$ tej serii ukazały się m.in. następujące prace: J. Borowski, Tryb życia chorego na serce, PZWL, Łódź 1961; J. Mowszowicz, Z. Chilarska, Z. Kotnowska, R. Olaczek, Parki Łodzi, PWN, Łódź 1962; W. Jasiewicki, Polska kinematografia w okresie filmu dźwiękowego (1930-1939), Ossolineum, Łódź 1967. 
Nowym wydawnictwem stały się zeszyty „Folia Medica Lodziensia”. Zaczęto je wydawać w 1965 r. ${ }^{32}$ Trzy lata później, biorąc pod uwagę problematykę wspólną dla środowisk ekonomicznych i prawniczych, ŁTN zaczęło wydawać czasopismo „Studia Prawno-Ekonomiczne"33.

Po 1956 r. gwałtownie wzrosła ilość opracowań wydawanych w ramach „Prac Wydziałów”. Rekordowymi pod tym względem okazały się lata 1961-1964. Do końca lat 60 . regularnie ukazywały się czasopisma naukowe.

Niekorzystne zmiany charakteryzujące się zmniejszeniem produkcji wydawniczej rozpoczęły się w latach 70. W 1970 r. restrykcje spotkały „Acta Anthropologica Lodziensia". Negatywne recenzje doprowadziły do skreślenia czasopisma z planu wydawniczego. Gdy Prezydium PAN podjęło decyzję, że nie powinny w planach wydawnictwa figurować publikacje zwarte i ciągłe z zakresu nauk ścisłych, przystąpiono do likwidacji serii wydawniczej „Folia Medica Lodziensia” i „Acta Chimica Lodziensia”"34.

W sytuacji kryzysowej wydawnictwo $Ł T N$ znalazło się w latach 80. W 1982 r. wstrzymane zostały prace wydawnicze na mocy dekretu o stanie wojennym. W 1983 i 1984 r. oprócz „Sprawozdań z Czynności i Posiedzeń Naukowych” i czterech czasopism, wydano tylko po jednym wydawnictwie zwartym. O istnieniu ścisłej cenzury świadczył fakt, że w 1986 r. Wydział I PAN zgłosił zastrzeżenia do "treści ideologicznych” znajdujących się w roczniku „Przeglądu Socjologicznego". Ponieważ wielkość dotacji PAN w latach 80. znacznie zmniejszyła się, wydawnictwo ŁTN zostało zmuszone do korekty planów i publikacji skromnej liczby tytułów w ograniczonym nakładzie.

W 1989 r. decyzją Sekretarza Generalnego PAN zostało wstrzymane finansowanie publikacji regionalnych towarzystw naukowych afiliowanych przy PAN. Pozostały one bez dotacji do 1991 r., a więc do czasu, gdy ich finansowanie przejął Komitet Badań Naukowych. ŁTN w tej sytuacji zmuszone było szukać sponsorów, którzy umożliwiliby prowadzenie działalności wydawniczej. Zdołano uzyskać wsparcie finansowe ze strony władz samorządowych Łodzi i województwa piotrkowskiego i sieradzkiego. Część publikacji wydano dzięki współpracy z dwiema wyższymi łódzkimi uczelniami, uniwersytetem i politechniką. Przedstawione trudności spowodowały, że w 1990 r. odnotowano najniższą produkcję wydawniczą ŁTN.

\subsection{Samodzielna polityka wydawnicza ŁTN po $1990 \mathrm{r}$.}

Od czasu, gdy PAN przestała pełnić rolę nadzorcy merytorycznego i finansowego, ŁTN mogło prowadzić samodzielną politykę wydawniczą. Na początku lat 90. zaczęły się kształtować jej zręby. Zapadły wówczas decyzje dotyczące

${ }^{32}$ Tamże, s. 180-193. Pierwszym redaktorem był prof. W. Markert. Wydawane w latach 19651973 i $1994-2012$.

${ }^{33}$ Tamże, s. 278-304. Pierwszym redaktorem był prof. J. Wróblewski. Wydawane w latach 1968-2012.

${ }^{34}$ Decyzja Prezydium PAN o zaniechaniu wydawania prac z zakresu nauk ścisłych zadecydowała o planach wydawniczych od 1.01.1974 $\mathrm{r}$. 
wznowienia czasopism zawieszonych i zainicjowane zostały prace nad nowymi periodykami i seriami wydawniczymi.

Ważnym posunięciem stało się przede wszystkim „przywrócenie życia” kilku czasopismom $^{35}$. Większość z nich jest wydawana do chwili obecnej. Dołączyły do nich nowe czasopisma: „Problemy Społecznego Ruchu Naukowego” w 1994 r. i „Studia Wyborcze” w 2006 r. W związku z utworzeniem Wydziału VI Sztuki i Nauk o Sztuce od 1999 r. wydawane jest czasopismo pt. „Art Inquiry - Recherches sur les arts". Na jego łamach są prezentowane poglądy dotyczące muzyki, plastyki, sztuk multimedialnych, teatru i filmu. Kolejne tomy mają charakter monograficzny. Wśród autorów artykułów oprócz polskich badaczy spotkać można przedstawicieli Niemiec, Wielkiej Brytanii, Włoch, USA. Teksty są drukowane w językach kongresowych.

Dążąc do integracji łódzkiego środowiska naukowego poprzez informowanie o różnych aspektach działalności badawczej i eksponowanie dokonań wybitnych uczonych, zapoczątkowano w latach 90 . wydawanie nowych serii. Należą do nich przede wszystkim: „Sylwetki łódzkich uczonych” i „Moja droga do nauki”. Prezentację wyróżniających się łódzkich profesorów wyższych uczelni rozpoczęto w 1991 r. ${ }^{36}$ Do listopada 2012 r. ukazało się 108 zeszytów ${ }^{37}$. Posiadają one podobną strukturę. Najpierw przedstawiany jest życiorys uczonego, następnie ma miejsce charakterystyka jego dorobku naukowego, a w trzeciej części zamieszczane są wspomnienia wychowanków i współpracowników. W większości przypadków zeszyty są wydawane z okazji uroczystości związanymi z urodzinami uczonych (głównie 70-lecie lub 80-lecie). Mała część dotyczy osób nieżyjących.

Seria wydawnicza „Moja droga do nauki” ma charakter autobiograficzny ${ }^{38}$. Wybitni łódzcy uczeni, należący do ŁTN, w zróżnicowany sposób ukazują swoje życie. Część z nich wiele miejsca poświęca opisowi środowiska rodzinnego i szkolnego, wskazując na czynniki i osoby mające wpływ na kształtowanie się ich zainteresowań nauką. Inni głównie skupiają się na okresie studiów i latach pracy w uczelni. Wspominają swoich mistrzów. Przedstawiają kolejne etapy działalności naukowej.

Obraz łódzkiego środowiska naukowego stał się bardziej wyrazisty dzięki zapoczątkowanej w 1994 r. serii wydawniczej „Informator nauki łódzkiej”. W ramach Informatora" wyodrębnione zostały podserie: stopnie, tytuły naukowe, stanowiska profesorskie ${ }^{39}$; towarzystwa i stowarzyszenia naukowe, specjalistyczne,

35 Wydawnictwo ŁTN wznowiło następujące czasopisma: 1991 r. - „Bulletin de la Société des Sciences et des Lettres de Łódź”, „Prace Polonistyczne”, „Przegląd Socjologiczny”, „Zagadnienia Rodzajów Literackich”; 1992 r. - „Biuletyn Peryglacyjny”, „Rozprawy Komisji Językowej”, „Studia Prawno-Ekonomiczne”; 1994 r. - „Folia Medica Lodziensia”.

${ }^{36}$ Pierwsze sylwetki ukazano w „Sprawozdaniach z Czynności i Posiedzeń Naukowych” w 1991 r. - Karol Dejna, w 1992 r. - Anna Dylikowa.

${ }^{37}$ Najwięcej opracowań dotyczy Wydziału III (33) i Wydziału II (26), a najmniej Wydziału VI (2) i Wydziału V (11). Zeszyt nr 93 pt. Profesor Szczepan Aleksander Pieniążek jest jedynym charakteryzującym osobę, która nie była członkiem $€ T N$.

${ }^{38}$ Kolejne tomy serii wydawniczej „Moja droga do nauki” ukazały się w latach 1996, 1997, 2000 , 2002, 2006, 2010. W sześciu tomach swe losy przedstawiło 49 osób.

39 Podseria zapoczątkowana w 1994 r. w postaci rocznika przedstawia osoby, które uzyskały stopień naukowy doktora, doktora habilitowanego, zostali nominowani do tytułu profesora. 
zawodowe $^{40}$; szkoły wyższe ${ }^{41}$; doktoraty honoris causa łódzkich uczelni ${ }^{42}$. Dopełnieniem „Informatora nauki łódzkiej” stała się seria „Rektorzy Państwowych Wyższych Uczelni w Łodzi"43.

Do nowych serii należą: „Konwersatorium wiedzy o mieście” 44 i „Materiały z sesji naukowych"45. Kontynuowana jest seria „Szlakami nauki”. W jej ramach obok publikacji prezentujących wyniki badań członków ŁTN wydrukowano szereg prac doktorskich obronionych na różnych wydziałach UŁ.

\section{Publikacje $Ł T N$ reprezentujące dorobek naukowy przedstawicieli łódzkiej pedagogiki i psychologii}

Od początku istnienia ŁTN w jego strukturach działali pracownicy naukowi reprezentujący pedagogikę i psychologię z UŁ. Wchodzili oni w skład Wydziału I i II. W latach 40. ich wypowiedzi były prezentowane w „Sprawozdaniach z Czynności i Posiedzeń” ŁTN. Swe poglądy w referatach przedstawili: Albert Dryjski, Sergiusz Hessen, Helena Radlińska, Stefan Truchim i Ryszard Wroczyński ${ }^{46}$.

W latach 50. i 60. przedstawiciele pedagogiki przygotowali artykuły do „Przeglądu Nauk Historycznych i Społecznych” (E. Podgórska i S. Truchim)47 i do „Przeglądu Socjologicznego" (A. Kamiński, K. Kotłowski, I. Muchnicka) ${ }^{48}$. W tym czasie starania ŁTN doprowadziły do druku kilku monografii napisanych przez osoby należące do łódzkiego środowiska pedagogicznego. Najpierw ukazała się praca A. Kamińskiego pt. Jaćwież (1953), a potem publikacje historyków wychowania ${ }^{49}$.

40 Podseria wydana w 1995 r. Przedstawia towarzystwa, stowarzyszenia, których siedziby są w Łodzi, a także te, których oddziały i filie działają na terenie regionu.

41 Podseria wydana w 1998 r. Charakteryzuje stan szkolnictwa wyższego (uczelnie państwowe i prywatne) w Łodzi w 1997 r.

42 Publikacja z 2000 r. zawierająca wykaz uczonych polskich i zagranicznych, którzy otrzymali tytuł doktora honoris causa w łódzkich szkołach wyższych.

43 Z tej serii wydano 3 tomy $(2002,2005,2011)$.

44 Seria ukazuje się od 1995 r. Prezentuje materiały przygotowane przez Katedrę Geografii Miast i Turyzmu UŁ i Komisję Geografii Osadnictwa i Ludności Polskiego Towarzystwa Geograficznego. Referaty dotyczą rozwoju centrów i peryferii dużych miast.

45 Seria ukazuje się od 1992 r. Obejmuje materiały z sesji naukowych, których organizatorami są Wydziały ŁTN.

46 W latach 1947-1949 w „Sprawozdaniach...” ŁTN wydrukowano następujące referaty: A. Dryjski - Psychologia ekstazy religijnej; S. Hessen - Zagadnienie różnicy prawa i moralności w filozofii starożytnej; H. Radlińska - Walka o duszę ludu; H. Radlińska - Działalność Wydziału Rozszerzania Oświaty Towarzystwa Naukowego z Uniwersytetem Krakowskim złączonego; S. Truchim - Wzajemne stosunki pijarów i Komisji Edukacji Narodowej; S. Truchim - Polska a pierwsza reforma szkolnictwa w Rosji; R. Wroczyński - Zmierzch pozytywizmu oświatowego w Polsce.

47 Bibliografia wydawnictw Towarzystwa Przyjaciół Nauk..., s. 219-220.

48 Tamże, s. 221, 223-224.

49 S. Truchim, Współpraca polsko-rosyjska nad organizacją szkolnictwa rosyjskiego w początkach XIX wieku, Łódź 1960; tenże, Historia szkolnictwa i oświaty polskiej w Wielkim Księstwie Poznań- 
Dzięki wydawnictwu ŁTN przedstawiono również dyskusję dotyczącą metodologii badań z zakresu historii oświaty, która odbyła się w UŁ w 1965 r. ${ }^{50}$ Do monografii w latach 70. dołączyła jeszcze praca I. Lepalczyk ${ }^{51}$.

W latach 80. przedstawiciele pedagogiki i psychologii zaczęli występować jako redaktorzy wydawnictw zwartych umieszczanych w ramach prac Wydziału I. W 1988 r. pod redakcją psychologa prof. Leona Niebrzydowskiego ukazała się praca pt. Rodzinne uwarunkowania kontaktów interpersonalnych dzieci i młodzieży. W latach 1988-1989 wydano dwie prace zbiorowe pod redakcją prof. I. Lepalczyk i prof. Ewy Marynowicz-Hetki ${ }^{52}$.

Po 1990 r. szczególnie aktywną osobą $w \measuredangle T N$ stała się przedstawicielka pedagogiki społecznej, prof. E. Marynowicz-Hetka. Przygotowana i poprowadzona przez nią debata panelowa (październik 1997 r.) pobudziła członków ŁTN do wymiany poglądów na rolę mistrza w świecie akademickim ${ }^{53}$. W podjętej dyskusji zastanawiano się nad charakterem relacji mistrz - uczeń, snuto rozważania nad potrzebą istnienia i tworzenia szkół naukowych. Znaczna część osób spośród zabierających głos była zdania, że dbając o przyszłość uprawianej dyscypliny należy zastanowić się nad modelem kształtowania następców w nauce, odnieść się do etosu pracy naukowej. Zainteresowanie tematyką spowodowało, że prof. E. Marynowicz-Hetka przygotowała w 2003 r. publikację zawierającą wypowiedzi kilku dyscyplin na temat szkół naukowych ${ }^{54}$.

Od 2000 r. ŁTN organizuje cykl seminariów dla uczestników studiów interdyscyplinarnych III stopnia. Prof. E. Marynowicz-Hetka, uczestnicząc w prowadzeniu zajęć, skupiła uwagę na problemie „kształcenia do profesji społecznych”. Uwzględniając zainteresowanie tym tematem teoretyków i praktyków reprezentujących środowisko pedagogiczne, przygotowała do druku w $Ł T N$ publikację ${ }^{55}$. W pracy tej znalazły się m.in. wypowiedzi profesorów pedagogiki: Bogusława Śliwerskiego i Krzysztofa J. Szmidta.

ŁTN stało się projektodawcą dwu publikacji dotyczących roli nauczycieli i szkolnictwa łódzkiego w tworzeniu dziedzictwa kulturowego Łodzi ${ }^{56}$. Duży udział

skim 1815-1915, t. I i II, Łódź 1967-1968; E. Podgórska, Szkolnictwo elementarne w Łodzi w latach 1808-1914, Łódź 1966.

${ }^{50}$ Z zagadnień metodologicznych historii wychowania: sprawozdanie z Sympozjonu Katedry Historii Wychowania i Oświaty UŁ i Katedry Pedagogiki Uniwersytetu im. Adama Mickiewicza w Poznaniu, oprac. S. Truchim, Łódź 1965.

51 I. Lepalczyk, Pedagogika biblioteczna Heleny Radlińskiej, Łódź 1974.

52 Instytucjonalna pomoc dziecku i rodzinie: diagnozy i propozycje, red. I. Lepalczyk, E. Marynowicz-Hetka, Łódź 1988; Rodzina z problemem alkoholowym: pomoc, profilaktyka, red. I. Lepalczyk, E. Marynowicz-Hetka, Łódź 1989.

${ }^{53}$ Mistrz - uczeń: wyobrażenia czy rzeczywistość, czyli o tworzeniu szkół naukowych, oprac. E. Marynowicz-Hetka, Łódź 1997.

${ }_{54}$ Szkoły naukowe w Łodzi akademickiej: o trwaniu dyscyplin i tradycji naukowej, oprac. E. Marynowicz-Hetka, Łódź 2003.

${ }_{55}$ Badanie - działanie - kształcenie, czyli o przydatności dyscyplin społecznych dla doskonalenia praktyki profesji społecznych w dziedzinie oświaty, kultury i pracy socjalnej, red. E. Marynowicz-Hetka, Łódź 2008.

${ }^{56}$ Rola nauczycieli łódzkich w tworzeniu dziedzictwa kulturowego Łodzi, red. S. Gala, Łódź 1999; Rola szkolnictwa łódzkiego w tworzeniu dziedzictwa kulturowego Łodzi w XX wieku, red. T. Jałmużna, Łódź 2003. 
w realizacji tego projektu mieli historycy wychowania. Oprócz profesorów - T. Jałmużny i E. Podgórskiej - w obu pracach przedstawili wyniki swoich badań niesamodzielni pracownicy naukowi Katedry Historii Wychowania i Pedeutologii UŁ.

Przedstawiciele pedagogiki aktywnie uczestniczyli przy tworzeniu serii wydawniczych „Moja droga do nauki” i „Sylwetki łódzkich uczonych”. W pierwszej serii znalazły się autobiografie prof. E. Podgórskiej ${ }^{57}$ i prof. I. Lepalczyk ${ }^{58}$. Do grona wybitnych łódzkich uczonych, których sylwetki zaprezentowane zostały w drugiej serii, należy zaliczyć profesorów: E. Podgórską, I. Lepalczyk, A. Kamińskiego, H. Radlińską i Olgę Czerniawską. W roczniku „Sprawozdania z Czynności i Posiedzeń Naukowych" zostały zamieszczone nekrologi zmarłych członków ŁTN, będących przedstawicielami łódzkiego środowiska pedagogicznego i psychologicznego.

Udział łódzkich psychologów w pracach wydawniczych ŁTN jest skromny. Na wyróżnienie zasługuje działalność podejmowana w ostatnich latach przez prof. Eleonorę Bielawską-Batorowicz. Informacja o prowadzonych przez nią badaniach znalazła się w „Spawozdaniach...” ŁTN w 2008 r. ${ }^{59}$

\section{Próba oceny działalności wydawnictwa ŁTN}

W 2011 r. uroczyście obchodzono 75. rocznicę powstania $Ł T N^{60}$. Zwrócono wówczas uwagę na to, że jednym z ważnych nurtów działalności stowarzyszenia jest praca wydawnicza. Od 1946 r. wydawnictwo ŁTN stworzyło szansę prezentowania i upubliczniania dorobku łódzkiego środowiska naukowego. Imponujący potencjał intelektualny tkwiący w tym środowisku został wykorzystany w tworzeniu specjalistycznych czasopism i serii wydawniczych, które osiągnęły wysoką pozycję na rynku wydawnictw naukowych w kraju, a w pewnych przypadkach również za granicą.

Najliczniej w dorobku edytorskim ŁTN reprezentowane są nauki humanistyczne (archeologia, historia, językoznawstwo, literaturoznawstwo, socjologia), nauki biologiczne i medyczne oraz geografia i geologia. Publikacje z ich zakresu są drukowane w ramach serii „Prace Wydziałów” oraz w specjalistycznych czasopismach. Po 1990 r. znacznie poszerzyła się problematyka badań obejmujących obszar Łodzi i regionu. Skutkowało to znacznym wzrostem wydawnictw z zakresu geografii 61 .

57 E. Podgórska, Nauczyciele w moim życiu i wspomnieniach, [w:] Moja droga do nauki, Łódź 1966, s. 275-296.

58 I. Lepalczyk, Radości na trudnych drogach, [w:] Moja droga..., s. 55-90.

59 E. Bielawska-Batorowicz, Psychologia prokreacji - koncepcja i wybrane obszary badań, „Sprawozdania...” 2008, t. 62, s. 153-160.

60 Obchody 75-lecia Łódzkiego Towarzystwa Naukowego http://www.wiadomosci24.pl/artykul/ obchody_75_lecia_lodzkiego_towarzystwa_naukowego_217539.html

61 Szczególną rolę w rozwoju badań regionalnych odegrał prof. Stanisław Liszewski, który od 1991 r. pełni funkcję Prezesa ŁTN. 
W latach 90. uruchomiono dwie serie wydawnicze dostarczające informacji o kształtowaniu się łódzkiego środowiska naukowego. Zeszyty zatytułowane „Sylwetki łódzkich uczonych" stanowią dokumentację dorobku naukowego łódzkich profesorów. Kolejne tomy serii „Moja droga do nauki” pozwalają na podstawie wspomnień i refleksji łódzkich akademików określić, jakie były korzenie tego środowiska, jaki był wkład przedstawicieli elity intelektualnej skupionej w $Ł T N$ do rozwoju nauki w Polsce i poza jej granicami.

Po wieloletnim wpływie PAN na plany wydawnicze ŁTN (cenzura, wysokość dotacji) od roku 1989 sytuacja uległa zmianie. Wydawnictwo ŁTN może prowadzić samodzielną politykę wolną od wpływów ideologicznych. Jednakże zaprzestanie finansowania działalności ŁTN przez PAN wymusiło na stowarzyszeniu konieczność podejmowania starań o środki finansowe od władz samorządowych i różnorakich firm. Komercjalizacja nauki, wolny rynek pracy nauczycieli akademickich to realia, które stanowią zagrożenie dla dynamicznej działalności ŁTN. Jednakże inicjatywy podejmowane po 2000 r. świadczą o krystalizowaniu się wizji rozwoju wydawnictwa ŁTN w nowych warunkach. Na efekty podejmowanych działań należy jednak poczekać. 